\title{
Judicious-medical opinions in cases for cancellation of testament including people who stayed in hospices or were covered by another form of palliative care
}

\begin{abstract}
It should be emphasized that in Poland wills are often made during the period when the testator is in a period of very advanced disease, such as cancer. By making a will, the testator may, at his own discretion, prefer to divide his property without having to resort to statutory regulations in this regard. The testament, as long as the testator is alive, has no effect and can always be dismissed in whole or in part, as a result of the principle of freedom of testing. Therefore, the testator may at any time revoke or change the individual provisions contained in the will or the entire will. Investigative material were judicial files in 471 testament cases sent from courts from all over Poland in years 1990-2017 in aim of elaborating judicious-medical opinions in this case studies. Usually the testament in Poland is only prepared in the face of the impending death. $48.6 \%$ of cases lacked the consciousness necessary to consent and $40.2 \%$ lack to freedom to express own will.
\end{abstract}

Keywords: judicious-medical opinions, testaments
Volume I Issue 2 - 2017

\author{
Jerzy T Marcinkowski, Aneta Klimberg \\ Department of Social Medicine, Poznan University of Medical \\ Sciences, Poland
}

Correspondence: Jerzy T Marcinkowski, Poznan University of Medical Sciences (Poland), Chair of Social Medicine, Individual Specialist Practice Neurology, 5C Rokietnicka Street, 60-806, Poland,Email jmarcin@ump.edu.pl, jtmarcin@gmail.com

Received: March 23, 2017 | Published: May 16, 2017

\section{Introduction}

It should be emphasized that in Poland wills are often made during the period when the testator is in a period of very advanced disease, such as cancer. ${ }^{1}$ By making a will, the testator may, at his own discretion, prefer to divide his property without having to resort to statutory regulations in this regard. The testament, as long as the testator is alive, has no effect and can always be dismissed in whole or in part, as a result of the principle of freedom of testing. Therefore, the testator may at any time revoke or change the individual provisions contained in the will or the entire will.

Polish law distinguishes two types of wills: 1) simple wills and 2) special wills. ${ }^{2,3}$ Common testaments include: 1) a notarial deed; 2) a holographic (will) holographic; and 3) an official (allographic) testament. Specific wills include:oral testament, testament made during a voyage on a Polish naval or airship, military will. Specific testaments can only be made if, due to certain circumstances (e.g. fear of death of the testator), it is impossible or more difficult to draw up a will. An oral testament can be made as a special testament if at least one of the circumstances mentioned in Article $952 \S 1$ Civil Code: 1) there is a fear of the death of the testator,2) the conduct of the ordinary form of the will is due to special circumstances impossible or very difficult. Special testaments are temporally limited in power, i.e., according to art. 955 Civil Code. The special testament is no longer valid six months after the circumstances that justify failure to do so, unless the testator dies before the deadline expires. Fear of death of the testator cannot be assessed solely on the basis of the subjective feelings of the testator. Its existence must be objectively justified. There must be such conditions or emergencies, which, in the light of medical knowledge and life experience, can cause rapid death. In addition, the fear of death must exist at the time of the will. The oral testament is drawn up in such a way that the testator declares his or her will verbally, with the simultaneous presence of at least three witnesses. A smaller number of witnesses entail the nullity of the will, while the larger number remains unimportant to the validity of the will.

Important testament can be made by a testator who:

1. It has full legal capacity (of legal age and has not been partially or completely incapacitated).

2. It is of unsound mind and has expressed its willingness to knowingly and freely (without pressure from others, especially immediate family members) (Article 945 of the Civil Code).

3. Did not act on the basis of a material error justifying the assumption that if the testator did not act under the influence of error, he would not have made a will of the content or acted on the threat that he might fear that he or another person is in danger of serious danger Personal or property (Article 945 of the Civil Code).

Very important in preparing judicious-medical opinions is if testator had the ability to test at the date of preparing testament. ${ }^{4}$ Later loss of ability of testing have no impact on execution of testament prepared earlier.

Staff working in hospices or in palliative care should be aware that they prepared their medical records is often later physical evidence in litigation over the validity of the will.

Experts making opinion in testament cases evaluate:

1) Testament itself and circumstances of its preparation, but not evaluate the reliability of records. 
2) Witnesses statements (describes of everyday living, testing motivation).

3) Medical records (clinic records, hospital history, hospital treatment information cards, etc.).

\section{Research methods}

Investigative material were judicial files in 471 testament cases send from courts from all over Poland in years 1990-2017 to: 1) Chair and Department of Forensic Medicine of Poznan University of Medical Sciences and to: 2) Individual Specialist Practice Neurology the author of the article - in aim of elaboration judicious-medical opinions in this case studies.

The evidence gathered in the court file was different in relation to the volume (from a few dozen pages to several volumes of several hundred pages each) and the type of evidence. This material was usually:

i. Medical records: Original history of hospital illnesses (usually non-psychiatric, most of which do not coincide with the dates of making wills), information cards for hospital treatment, medical records (most often family doctors/general counseling), medical certificates Kind, including health certificates filled out on the official N-9 Social Insurance Institute for disability pensions).

ii. Testimony of the parties to the proceedings (participants in the proceedings)

iii. The testimony of the witnesses proposed by the parties to the process (usually family members, neighbors, fewer doctors, nurses, nannies Polish Red Cross, etc.).

In some court cases the evidence was:

i. Nursing documentation: Nurse reports from hospital duty, reports of the so-called environmental nurses who visit the sick at home.

ii. Documentation of hospices or terminal care services.

iii. Letters written by the testators (e.g. to indicate close links with a person named to inherit or prove the conflict and to justify a decision depriving the right to inherit the statutory successors).

iv. Photos of testators in the neighborhood of people interested in heredity.

$\mathrm{v}$. Various types of official documents signed by the testator.

Usually, the Court asked the expert the following question: "Did the testator, knowing his state of health and age, was able, at the day of his will, to consciously ${ }^{1}$ and freely ${ }^{2}$ decide and express his will?" Next to that question appeared also others, such as: "Is the state of health of the testator on the will affect medications?" (Usually it was about morphine administered to patients with cancer). ${ }^{1,5}$

${ }^{1}$ The ability to consciously adopting decisions are considered when assessing whether the testator - he wanted to make this particular legal action - reckoned with the fact that this action will cause him legal effects - reckoned with the fact that this action will bring certain legal consequences for its close - he predicted that this legal action arise, such as no other effects. ${ }^{4,5}$

${ }^{2}$ The psychic freedom of decision is determined by assessing whether or not the testator is able to take the legal action freely, or is influenced by an environment that he cannot control, or the motives for action are not subject to cognitive impairment and emotional disturbance. The performance of a given legal act was deliberate and beneficial to the judge. ${ }^{4,5}$

\section{Results}

In total, the testaments were predominantly (made up of notaries or self-written by the testator) - approximately $75 \%$ of special testaments, which were oral testaments)-about $25 \%$. In $64.0 \%$ of discussed cases gave opinion as first; in rest of cases previous judicious-medical opinions have been given, in 16 cases antagonistic. In $13.7 \%$ of cases wills were filed by patients living in hospices or under another form of palliative medicine. Although in most cases $(69.2 \%)$ have been left only one testament, but there were also cases $(3.2 \%)$ where have been left 5 testaments. Periods of outlive of devisors from the preparation of last testament were normally short. In total, testaments not only spoken but also made by notary were prepared by persons with chronic diseases with marked clinical symptoms, which were seemed as sign of soon death. It was often prepared in hospital room, in a hospice or notary office after transit there from a hospital or hospice.

Percentage of cases in which devisors were not able to prepare fully aware testaments were high; this was in the connection with fact that often preparing testament taken place in short period before death by chronically sick persons. There were the base to ascertain the lack of consciousness necessary to test in $48.6 \%$ of cases and in $40.2 \%$ lack of freedom to express own will. Medical records were present in all cases, in this in $21.5 \%$ cases psychiatric records and in $22.5 \%$ neurological consultations. In most of cases low quality of documentation was encumbrance in giving opinions. Fact that in most of cases testimonies of witnesses were highly different can be connected with lack of possibility to evaluate psychical state of devisor or were interested in result of the case. In many cases doctors treating patients on non-psychiatric wards were unable to answer questions about psychical state. They are concentrating mainly on somatic cause of hospitalization, and their contact with patient takes short period of time.

\section{Often situation was the following:}

An aging mother or father living alone and increasingly frail was more and more devoted to neighborly assistance. It usually started with bringing food and then helping to clean the apartment, in the laundry. Then help became more and more widespread. And then the sick father or mother made a will in which for long-term help they prescribed neighbors their own apartment. When finally a father or mother, suffering from severe illness, died, a son or daughter appeared, who for some decades had not had time to appear with his or her parents at all and help with anything. Now they pretended to fall by writing in the lawsuit to the court that the father or mother was dull or mentally ill and was unable to freely and consciously make a will.

\section{Discussion and conclusion}

If you analyze the periods experienced by the testator after the last testament was made, it is noted that they were generally short. This is due to the fact that generally speaking, not only verbal but also notarial, were drawn up by patients who were ill with a clear manifestation of clinical symptoms, which was perceived by the environment as the specter of the impending death. Hence uncommon preparing them to a hospital room or in a hospice or a notary after transport from the hospital or hospice. This is clearly evidenced by the fact that in about $7 \%$ of cases deaths have already occurred on the day of the will and in about $13 \%$ of cases within 1-5 days. Another $36 \%$ of the testators did not survive 1 month after the last testament was made. Only about $2 \%$ survived beyond 5 years after the last will. These facts show that usually the testament in Poland is only prepared in the face of the impending death. ${ }^{1}$ 
Problems with certification on the basis of medical records are connected with lack of psychiatrists or neurologists consultations from the period of testament preparing, sometimes there in no documentation from this period. It should be advised to persons who want to prepare testament to go to voluntary psychiatric examination in this period. ${ }^{6}$ Judicious-medical opinions in testament cases are difficult and time-consuming; much more difficult is defending one's rights in courts.

\section{Acknowledgements}

None.

\section{Conflict of interest}

The author declares no conflict of interest.

\section{References}

1. Skupień E. Opiniowanie w sprawach o unieważnienie testamentu lub umowy darowizny. Prawo i Medycyna. 2005;7(19):111-121.

2. Niedośpiał M. Wzory testamentów z komentarzem. Wydawnictwo STO, Bielsko-Biała, Poland: Springer; 2000. 189 p.

3. Drzewicki M. Spadek - dziedziczenie - testament. Wydawnictwo Harmonia, Poland: Springer; 2000. 104 p.

4. Pang YX, Cai WX, Zhang QT, et al. Advanced investigation of testamentary capacity of the mentally disordered. $\mathrm{Fa}$ Yi Xue Za Zhi. 2009;25(3):208-11.

5. Merikangas JR. Contested Wills and Will Contests. J Am Acad Psychiatry Law. 2015;43(3):293-297.

6. Filaković P, Erić AP, Mihanović M, et al. Dementia and legal competency. Coll Antropol. 2011;35(2):463-469. 